\title{
Hak Tanggungan Sebagai Jaminan Perlindungan Hukum Bagi Para Pihak Dalam Pembiayaan di Perbankan Syariah
}

\section{Triamita Rahmawati}

Magister Kenotariatan Fakultas Hukum Universitas Islam Indonesia Yogyakarta Indonesia Jln. Cik Di Tiro No. 1 Yogyakarta Indonesia triamitar@gmail.com

Key Word:
Guarantee, Mortgage
Right, Sharia
Banking

Abstract

Right, Sharia

The problems formulated in this study are first, how is the legality of mortgages as collateral in financing in Islamic banking, and second, about whether mortgage guarantees in financing in Islamic banking have the same position as in credit in conventional banking. This type of research is juridical, with a legal and conceptual approach, collecting data from research subjects, information and interviews based on qualitative analysis. The results of this study conclude that the Legality of Mortgage in financing in Islamic Banking is not only seen from the Mortgage Deed based on Law Number 4 of 1996, it can also be based on the Financial Services Authority Regulation Number 16/POJK.03/2014 so that Mortgage provides legal protection for parties in financing in Islamic banking. Mortgage rights in Islamic banking and conventional banking have different positions. In conventional banks, mortgages as collateral are the main things in providing credit and privileges for creditors, while in Islamic banking, guarantees do not have a privileged position in the provision of financing funds

\section{Kata-kata Kunci: \\ Hak Tanggungan, Jaminan, Perbankan Syariah}

\begin{abstract}
Abstrak
Masalah yang dirumuskan dalam penelitian ini, pertama, bagaimana legalitas hak tanggungan sebagai jaminan dalam pembiayaan di perbankan syariah, dan kedua, tentang apakah jaminan hak tanggungan dalam pembiayaan di perbankan syariah mempunyai kedudukan yang sama seperti halnya dalam kredit di perbankan konvensional. Jenis penelitian ini bersifat yuridis, dengan pendekatan undang-undang dan konseptual, mengumpulkan data yang bersumber dari subjek penelitian, informasi dan wawancara berdasarkan analisis kualitatif. Hasil penelitian ini menyimpulkan legalitas Hak Tanggungan dalam pembiayaan di Perbankan Syariah selain dilihat dari Akta Pembebanan Hak Tanggungan yang berlandaskan Undang-undang Nomor 4 Tahun 1996 dapat pula berdasarkan Peraturan Otoritas Jasa keuangan Nomor 16/POJK.03/2014, sehingga Hak Tanggungan memberikan perlindungan hukum bagi para pihak dalam pembiayaan di perbankan syariah. Hak tanggungan pada perbankan syariah dan perbankan konvensional mempunyai kedudukan yang berbeda. Dalam bank konvensional hak tanggungan sebagai jaminan merupakan hal yang pokok dalam pemberian kredit dan privilege (istmewa) bagi kreditur sedangkan dalam pembiayaan di perbankan syariah jaminan tidak berkedudukan privilege dalam pemberian dana pembiayaan
\end{abstract}

\section{Pendahuluan}

Perkembangan yang signifikan dalam bidang perbankan syariah di Indonesia terjadi pada 2008, yakni dengan diundangkannya Undang-Undang Nomor 21 Tahun 2008 tentang Perbankan Syariah (selanjutnya disebut UU Perbankan Syariah). Diundangkannya undang-undang ini dilatarbelakangi oleh meningkatnya kebutuhan 
masyarakat terhadap jasa-jasa perbankan syariah. Sementara itu, pengaturan mengenai Perbankan Syariah di dalam Undang-Undang Nomor 10 Tahun 1998 tentang Perubahan Atas Undang-Undang Nomor 7 Tahun 1992 tentang Perbankan belum spesifik sehingga perlu diatur secara khusus dalam suatu undang-undang tersendiri.

Kegiatan bank syariah sebagaimana yang diatur dalam UU Perbankan Syariah pada dasarnya ada tiga macam, yaitu berupa pendanaan, jasa, dan pembiayaan. Kegiatan pendanaan berupa menghimpun dana dalam bentuk tabungan, giro, dan deposito. Untuk tabungan dan deposito dilakukan dengan akad mudharabah, sedangkan untuk giro dengan akad wadi'ah. Transaksi menghimpun dana tersebut dapat dilakukan dengan akad lain yang tidak bertentangan dengan prinsip syariah. Kemudian kegiatan yang berupa pelayanan jasa antara lain melakukan pengambilalihan utang berdasarkan akad hawalah. Melakukan fungsi wali amanat berdasarkan akad wakalah. Transaksi penyaluran pembiayaan dengan akad qard.

Kegiatan bank syariah yaitu pembiayaan, yang merupakan pendanaan yang dikeluarkan untuk mendukung investasi yang telah direncanakan, baik dilakukan sendiri maupun dijalankan oleh orang lain. Dana tersebut harus digunakan dengan benar, adil, dan harus disertai dengan ikatan dan syarat-syarat yang jelas. Pada dasarnya pembiayaan diberikan oleh bank kepada nasabah atas dasar kepercayaan. Sehingga dapat dikatakan bahwa pembiayaan adalah pemberian kepercayaan. Hal ini berarti prestasi yang diberikan benar-benar diyakini dapat dikembalikan oleh nasabah pembiayaan sesuai dengan waktu dan syarat-syarat yang telah disepakati oleh kedua belah pihak. ${ }^{1}$

Bank syariah dalam menjalankan fungsi sebagai lembaga intermediasi, mensyaratkan adanya jaminan kepada nasabah yang hendak mendapatkan pembiayaan. Meskipun aturan mengenai adanya jaminan dalam Undang-undang Perbankan Syariah tidak disebutkan secara jelas, namun dalam pelaksanaannya, jaminan bertujuan untuk menjalankan prinsip-prinsip kehati-hatian (Prudential Banking Regulation) serta menjamin kelangsungan hidup dan kesehatan bank tetap terjaga.

Di dalam Undang-Undang Nomor Nomor 21 Tahun 2008 tentang Perbankan Syariah digunakan istilah agunan untuk memaknai jaminan. Agunan adalah jaminan tambahan, baik berupa benda bergerak maupun benda tidak bergerak yang diserahkan oleh pemilik agunan kepada Bank Syariah dan/atau UUS (Unit Usaha Syariah), guna menjamin pelunasan kewajiban Nasabah penerima fasilitas. ${ }^{2}$

Pemberian jaminan yang diterapkan oleh perbankan syariah merupakan cara bank dalam mengikat nasabah agar memenuhi kewajibannya sebagaimana yang telah disepakati pada saat akad. Pengikatan jaminan antara nasabah dengan pihak bank dituangkan dalam bentuk perjanjian jaminan yang berisi tentang kesanggupan debitur atau pihak ketiga dalam menjamin pelunasan hutang yang diperoleh dari kredit atau pembiayaan. ${ }^{3}$

1 Ismail Nawawi, Perbankan Syariah, Kencana, Jakarta, 2011, hlm. 107

2 Dewi Nurul Musjtari, Penyelesaian Sengketa Akad Pembiayaan dengan Jaminan Hak Tanggungan dalam Praktik Perbankan Syariah, Parama Publishing, Yogyakarta, 2016, hlm. 132

${ }^{3}$ A. Wangsawidjaja Z, Pembiayaan Bank Syariah, Gramedia Pustaka Utama, Jakarta, 2012, hlm. 285. 
Salah satu bentuk jaminan dalam perbankan syariah adalah jaminan atas tanah. Dalam prakteknya jaminan atas tanah dalam perbankan syariah guna menjamin kepastian hukum terhadap jaminan yang diberikan oleh nasabah penerima fasilitas kepada bank, maka bank syariah melakukan hal yang sama seperti perbankan konvensional yaitu melakukan pembebanan Hak Tanggungan terhadap jaminan atas tanah tersebut melalui Pejabat yang berwenang yaitu dalam hal ini adalah Pejabat Pembuat Akta Tanah (selanjutnya disebut PPAT).

Proses pembebanan Hak Tanggungan dilaksanakan melalui dua tahap kegiatan, yaitu melalui tahap pemberian Hak Tanggungan yang didahului dengan perjanjian utang piutang yang dijamin kemudian dilakukan pembuatan Akta Pemberian Hak Tanggungan oleh Pejabat Pembuat Akta Tanah (PPAT), dan selanjutnya adalah tahap pendaftarannya oleh Kantor Pertanahan. Berdasarkan Pasal 13 UUHT ayat (5), Hak Tanggungan lahir pada hari tanggal buku tanah Hak Tanggungan didaftarkan. ${ }^{4}$

Untuk menghindari masalah dalam menjalankan tugasnya, bank syariah menerapkan konsep hak tanggungan yang umum diterapkan dalam bank konvensional. Sebagaimana diketahui, bahwasanya hak tanggungan merupakan satu-satunya lembaga jaminan atas tanah yang diterapkan oleh Negara Indonesia. Namun, konsep hak tanggungan apabila diterapkan pada bank syariah akan menjadi suatu hal yang rancu, karena pada dasarnya hak tanggungan digunakan untuk jaminan atas perjanjian utangpiutang antara debitur dengan kreditur. Sedangkan dalam bank syariah tidak ada perjanjian utang-piutang melainkan pembiayaan dan tidak ada pula istilah utangpiutang, namun pembiayaan yang dilakukan oleh nasabah dan pihak bank.

Pembebanan Hak Tanggungan dalam perbankan syariah menimbulkan problematika terhadap PPAT, karena bentuk dari APHT maupun SKMHT yang dibuat oleh PPAT merupakan bentuk baku/standar yang telah ditentukan oleh Kantor Pertanahan, hal tersebut sesuai dengan Peraturan Kepala Badan Pertanahan Republik Indonesia Nomor 8 Tahun 2012 tentang Perubahan Atas Peraturan Menteri Negara Agraria/Kepala Badan Pertanahan Nasional Nomor 3 Tahun 1997 tentang Pelaksanaan Peraturan Pemerintah Nomor 24 Tahun 1997 tentang Pelaksanaan Peraturan Pemerintah Nomor 24 Tahun 1997 tentang Pendaftaran Tanah pada Pasal 96 ayat (1) huruf f tentang Akta Pemberian Hak Tanggungan dan huruf $h$ tentang SKMHT yang tata cara pengisiannya harus dibuat sesuai dengan lampiran peraturan tersebut. Selanjutnya di dalam Pasal 96 ayat (3) juga menyebutkan bahwa "pendaftaran perubahan data pertanahan dan pembuatan APHT tidak dapat dilakukan berdasarkan akta yang pembuatannya tidak sesuai dengan ketentuan ayat (1)", juncto Pasal 96 ayat (5) yang menyebutkan bahwa "Kepala Kantor Pertanahan menolak pendaftaran akta PPAT yang tidak sesuai dengan ketentuan sebagaimana diatur pada ayat (1)." Ketentuan sebagaimana yang diatur dalam ayat (1) tersebut yang dimaksud adalah ketentuan pembuatan akta-akta yang diantaranya adalah APHT dan SKMHT yang sudah ditentukan tata cara pengisiannya sesuai dengan lampiran yang ada dalam peraturan tersebut.

${ }^{4}$ Kartini Muljadi dan Gunawan Widjaja, Hak Tanggungan, Kencana Prenada Media Group, Jakarta 2005, hlm. 214. 


\section{Rumusan Masalah}

1. Bagaimanakah legalitas hak tanggungan sebagai jaminan dalam pembiayaan di Perbankan Syariah?

2. Apakah jaminan hak tanggungan dalam pembiayaan di Perbankan Syariah mempunyai kedudukan yang sama seperti halnya dalam kredit di perbankan konvensional?

\section{Tujuan Penelitian}

1. Untuk mengetahui legalitas hak tanggungan sebagai jaminan dalam pembiayaan di Perbankan Syariah

2. Untuk mengetahui jaminan hak tanggungan dalam pembiayaan di Perbankan Syariah mempunyai kedudukan yang sama seperti halnya dalam kredit bank konvensional

\section{Metode Penelitian}

Penelitian ini menggunakan metode normatif pendekataan perundang-undangan (statute apporoach), dan pendekatan konseptual (conceptual apporoach). Sumber data dari penelitian ini bersumber dari data primer dan sekunder. Data primer diperoleh melalui wawancara, sedangkan data sekunder diperoleh melalui studi dokumen tertulis.

\section{Hasil Penelitian dan Pembahasan}

\section{Legalitas Hak Tanggungan dalam Pembiayaan di Perbankan Syariah}

Legalitas Hak Tanggungan dalam pembiayaan di perbankan syariah dapat dilihat dari adanya lembaga Hak Tanggungan yang berdasarkan Undang-Undang Nomor 4 Tahun 1996 tentang Hak Tanggungan atas Tanah Beserta Benda-Benda yang Berkaitan dengan Tanah (selanjutnya disebut Undang-Undang Hak Tanggungan) terkait dengan legalitas pembebanan hak tanggungan pada perbankan syariah didasarkan pada bentuk Akta Pembebanan Hak Tanggungan (APHT) dan/atau Surat Kuasa Membebankan Hak Tanggungan (SKMHT) yang dibuat oleh Pejabat Pembuat Akta Tanah (PPAT), yang selanjutnya dikaitkan dengan makna akad-akad dalam pembiayaan di bank syariah. Selain itu, legalitas hak tanggungan dalam pembiayaan di perbankan syariah dapat dilihat pula dengan adanya Peraturan Otoritas Jasa Keuangan Nomor 16/POJK.03/2014 tentang Penilaian Kualitas Aset Bank Umum Syariah dan Unit Usaha Syariah.

Pasal 1 angka 1 UUHT, menyebutkan bahwa yang dimaksud dengan hak tanggungan adalah hak jaminan yang dibebankan pada hak atas tanah sebagaimana dimaksud dalam Undang-Undang Nomor 5 Tahun 1960 tentang Peraturan Pokok-pokok Agraria, berikut atau tidak berikut benda-benda lain yang merupakan satu kesatuan dengan tanah itu, untuk pelunasan utang tertentu, yang memberikan kedudukan yang diutamakan kepada kreditor tertentu terhadap kreditor-kreditor lain. Dari penjelasan tersebut, menekankan bahwa adanya hak tanggungan sebagai jaminan untuk pelunasan 
utang yang selama ini lebih dikenal pada perbankan konvensional. Sedangkan dalam perbankan syariah istilah yang dikenal untuk utang atau kredit ialah pembiayaan.

Undang-Undang Nomor 21 Tahun 2008 tentang Perbankan Syariah menjelaskan bahwa pembiayaan adalah penyediaan dana atau tagihan yang dipersamakan dengan itu berupa:

a. Transaksi bagi hasil dalam bentu mudharabah dan musyarakah

b. Transaksi sewa-menyewa dalam bentuk ijarah atau sewa beli dalam bentuk ijarah muntahiya bittamalk

c. Transaksi jual beli dalam bentuk piutang qardh;dan

d. Transaksi sewa-menyewa jasa dalam bentuk ijarah untuk transaksi multijasa.

Berdasarkan persetujuan atau kesepakatan antara Bank Syariah dan/atau UUS dan pihak lain yang mewajibkan pihak yang dibiayai dan/atau diberi fasilitas dana untuk mengembalikan dana tersebut setelah jangka waktu tertentu dengan imbalan ujrah, tanpa imbalan, atau bagi hasil.

Pasal 36 Undang-Undang Nomor 21 Tahun 2008 menyebutkan dalam menyalurkan pembiayaan dan melakukan kegiatan usaha lainnya, Bank Syariah dan UUS wajib menempuh cara-cara yang tidak merugikan Bank Syariah dan/atau UUS dan kepentingan Nasabah yang mempercayakan dananya. Salah satu cara yang dilakukan oleh bank syariah ialah mensyaratkan adanya jaminan kepada nasabah yang hendak mendapatkan pembiayaan. Adanya jaminan bertujuan untuk menjalankan prinsip kehati-hatian serta menjamin kelangsungan hidup dan kesehatan bank tetap terjaga.

Untuk memaknai jaminan, bank syariah menggunakan istilah agunan. Agunan adalah jaminan tambahan, baik berupa benda bergerak maupun benda tidak bergerak yang diserahkan oleh pemilik agunan kepada bank syarah dan/atau UUS, guna menjamin pelunasan kewajiban nasabah penerima fasilitas. Salah satu jaminan/agunan yang banyak digunakan oleh perbankan syariah ialah Hak Tanggungan.

Utang atau kredit dan pembiayaan merupakan fasilitas penyediaan dana yang diberikan oleh perbankan, akan tetapi secara prinsip utang/kredit dengan pembiayaan secara garis besar merupakan suatu hal yang berbeda. Perbedaan itu dapat dilihat dari keuntungan atau imbalan yang diterima oleh bank atas penyediaan dana yang bank berikan. Pada kredit/utang yang diberikan oleh bank konvensional pengembalian atas dana yang dipinjamkan disertai dengan adanya pemberian bunga, sedangkan di dalam perbankan syariah tidak dikenal bahkan dilarang adanya pemberian bunga/riba. ${ }^{5}$ Selain itu, perbedaan antara pembiayaan dengan utang/kredit yang lain ialah bahwa dalam perbankan konvensional penyediaan dana mutlak dengan utang/kredit sedangkan di dalam perbankan syariah penyediaan dana harus dilihat terlebih dahulu bentuk akadakad dalam perbankan syariah itu sendiri.

Salah satu bank syariah yang menggunakan hak tanggungan sebagai jaminan yaitu bank BNI Syariah Kantor Cabang Yogyakarta. Akad pembiayaan yang digunakan oleh bank BNI Syariah Kantor Cabang Yogyakarta dengan jaminan hak tanggungan berupa akad pembiayaan murabahah, mudharabah, dan musyarakah. ${ }^{6}$

5 Agus Triyanta, Hukum Perbankan Syariah, Setara Press, Malang, 2016, hlm. 43.

${ }^{6}$ Berdasarkan Hasil Wawancara dengan Bapak Daryoko Pegawai Bank BNI Syariah bagian Legal di Kantor Cabang Yogyakarta pada 24 November 2020. 
Prosedur pembebanan hak tanggungan pada bank syariah, khususnya Bank BNI Syariah sama seperti pembebanan hak tanggungan pada bank konvensional, yaitu menggunakan Undang-Undang Nomor 4 Tahun 1996 sebagai landasan peraturannya. ${ }^{7}$ Pasal 10 ayat (1) dan (2) UUHT menyebutkan bahwa pemberian Hak Tanggungan didahului dengan janji memberikan Hak Tanggungan sebagai jaminan pelunasan utang tertentu, yang dituangkan di dalam dan merupakan bagian tak terpisahkan dari perjanjian utang-piutang yang bersangkutan atau perjanjian lainnya yang menimbulkan utang tersebut. Pemberian Hak Tanggungan dilakukan dengan pembuatan Akta Pemberian Hak Tanggungan oleh PPAT sesuai dengan peraturan perundang-undangan yang berlaku. Pemberian Hak Tanggungan juga wajib didaftarkan pada Kantor Pertanahan.

Sebagaimana ketentuan dalam Pasal 10 ayat (2) UUHT, maka terhadap pembuatan akta APHT harus dibuat oleh PPAT berdasarkan peraturan perundang-undangan yang berlaku. Sehingga pembuatan akta PPAT harus didasarkan pada Peraturan Kepala Badan Pertanahan Nasional Nomor 8 Tahun 2012 tentang Pelaksanaan Peraturan Pemerintah Nomor 24 Tahun 1997 tentang Pendaftaran Tanah (selanjutnya disebut Perkaban Nomor 8 Tahun 2012). Peraturan tersebut merupakan petunjuk bagi PPAT untuk membuat akta (diantaranya SKMHT dan APHT), dalam aturan tesebut dilampirkan juga bentuk dari SKMHT maupun APHT yang wajib dijadikan dasar petunjuk bagi PPAT dalam membuat akta yang berkaitan dengan pembebanan Hak Tanggungan.

Redaksi dalam lampiran SKMHT dan APHT pada Perkaban Nomor 8 Tahun 2012 dapat dikatakan/disediakan untuk kepentigan utang/kredit dalam perbankan konvensional. Bunyi redaksi APHT yang terlampir pada Perkaban tersebut ialah sebagai berikut:

a) Penyebutan Debitor dan Kreditor sebagai para pihak

b) Penyebutan "...telah ditandatangani perjanjian utang piutang..."

c) Penyebutan "...bahwa untuk menjamin pelunasan utang...".

Redaksi-redaksi di atas, merupakan redaksi baku yang digunakan sebagai petunjuk tata cara pengisian APHT oeh PPAT dalam membebankan Hak Tanggungan. Dapat disimpulkan bahwa adanya Hak Tangggungan itu sendiri karena adanya suatu perjanjian utang/ kredit.

Dalam prakteknya, agar redaksi dalam APHT sesuai dan selaras dengan perbankan syariah, maka PPAT menselaraskan redaksi-redaksinya dengan merubah perjanjian utang piutang dengan pembiayaan, Debitor menjadi Nasabah atau Penerima Fasilitas Pembiayaan dan Kreditor menjadi Bank/Penyediaan Dana. ${ }^{8}$ Hal itu dilakukan karena belum ada peraturan khusus tentang penjaminan pada perbankan syariah. Oleh sebab itu, Kantor Petanahan memberi toleransi bank syariah dalam pembebanan hak tanggungan sebagai jaminanan.

7 Berdasarkan Hasil Wawancara dengan Notaris/PPAT Kota Yogyakarta Bapak Rio Kustianto Wironegoro di Yogyakarta pada 26 November 2020

8 Berdasarkan Hasil Wawancara dengan Notaris/PPAT Kota Yogyakarta Bapak Rio Kustianto Wironegoro di Yogyakarta pada 26 November 2020 
Menurut penulis, mentolerir redaksi APHT yang sudah ditentukan oleh Perkaban dalam pemebebanan hak tanggungan pada perbankan syariah merupakan pelanggaran terhadap Perkaban dan tidak konsistennya Kantor Pertanahan dalam penerapan Perkaban itu sendiri. Redaksi tersebut sangat substansial karena redaksi perjanjian utang yang menjadi dasar pembebanan hak tanggungan tidaklah dapat dipersamakan dengan pembiayaan pada perbankan syariah.

Sebagaimana Pasal 96 ayat (2) Perkaban Nomor 8 Tahun 2012, pembuatan akta sebagaimana dimaksud dalam Pasal 95 ayat (1) dan ayat (2) harus dilakukan dengan menggunakan formulir sesuai dengan bentuk sebagaimana dimaksud pada ayat (1) yang disediakan. Pasal 96 ayat (3) menyebutkan pendaftaran perubahan data pendaftaran tanah sebagaimana dimaksud dalam Pasal 95 ayat (1) dan pembuatan Akta Pemberian Hak Tanggungan sebagaimana dimakud dalam Pasal 95 ayat (2) tidak dapat dilakukan berdasarkan akta yang pembuatannya melanggar ketentuan pada ayat (2). Pasal 95 ayat (1) menjelaskan akta tanah yang buat oleh PPAT untuk dijadikan dasar pendaftaran perubahan data pendaftaran tanah yang pada huruf (f) pasal tersebut ialah Akta Pemberian Hak Tanggungan.

Fatwa Dewan Syariah Nasional No: 68/DSN-MUI/III2008 tentang Rahn Tanjily yang menyebutkan bahwa jaminan dalam bentuk barang atas utang tetapi barang jaminan tersebut (marhun) tetap berada dalam penguasaan (pemanfaatan) Rahin dan bukti kepemilikannya diserahkan kepada murtahin, mempunyai substansi yang sama dengan Hak Tanggungan. Dalam Hak Tanggungan, jaminan yang dibebankan pada hak atas tanah berikut atau tidak berikut benda-benda yang berkaitan dengan tanah tetap berada dalam penguasaan debitor dan bukti pembebanan atas tanah untuk hak tanggungan yaitu APHT dan/atau SKMHT diserahan kepada pihak kreditor. Namun, dalam implementasi tidak dapat dipersamakan dikarenakan Rahn Tanjily berdasarkan pada pembiayaan dalam perbankan syariah sedangkan Hak Tanggung didasarkan pada perjanjian utang piutang.

UU Hak Tanggungan di dalam Pasal 10 ayat (1) secara tegas mengatakan bahwa pemberian Hak Tanggungan didahului dengan janji untuk memberikan Hak Tanggungan sebagai jaminan pelunasan utang tertentu, yang dituangkan di dalam dan merupakan bagian tak terpisahkan dari perjanjian utang-piutang yang bersangkutan atau perjanjian yang menimbulkan utang tersebut. Dari penjelasan tersebut Hak Tanggungan harus dan mutlak untuk pelunasan utang.

Menurut penulis, pembiayaan pada perbankan syariah bisa dibebankan jaminan hak tanggungan apabila dibuat grosse akta pengakuan utang dari nasabah, hal ini dikarenakan pembiayaan berbeda dengan perjanjian utang. Namun, dalam pelunasan pembiayaan menimbulkan utang-piutang antara bank dengan nasabah sehingga perlu dibuat grosee akta pengakuan utang sebagai landasan dibebankannya Hak Tanggungan. Grosse akta pengakuan utang merupakan suatu akta yang berisi pengakuan utang sepihak, dimana Debitur (nasabah) mengakui bahwa dirinya mempunyai kewajiban membayar kepada kreditur (bank) sejumlah uang dengan jumlah yang pasti (tetap). Grosse akta pengakuan utang dibuat oleh debitur dengan akta notaris menggunakan kepala akta yang bertuliskan "Demi Keadilan Berdasarkan Ketuhanan Yang Maha Esa". Dengan irah-irah pada kepala akta tersebut, maka grosse akta pengakuan utang mempunyai kekuatan eksekutorial. 
Meskipun akta pengakuan utang bersifat accessoire, artinya grosse akta tersebut selalu mengikuti perjanjian pokoknya. Apabila perjanjian pokoknya berakhir, maka grosse akta pengakuan utang menjadi berakhir pula. Sebuah utang yang telah dibayar lunas oleh debitur, berakibat menghapuskan perjanjian utang piutangnya. Dengan hapusnya perjanjian pokok tersebut berakibat grosse akta pengakuan utang menjadi tidak berguna lagi. ${ }^{9}$ Perjanjian pokok yang dimaksud adalah perjanjian pembiayaan yang dilakukan oleh pihak bank dan nasabah.

Untuk memperkuat legalitas pembebanan Hak Tanggungan dalam perbankan syariah, Peraturan Jasa Keuangan Nomor 16/POJK.03/2014 tentang Peniliaian Kualitas Aset Bank Bank Umum Syariah dan Unit Usaha Syariah dalam Pasal 46 ayat (1) mengatur bahwa agunan yang dapat diperhitungkan sebagai pengurangan PPA (Penyisihan Penghapusan Aset) adalah agunan yang dilengkapi dengan dokumen hukum yang sah dan diikat sesuai dengan peraturan perundang-undangan yang berlaku sehingga memberikan hak preferensi bagi bank. Adapun yang dimaksud dengan pengikatan yang memberikan hak preferensi adalah pengikatan yang dilakukan dengan gadai, hipotek, hak tanggungan dan fidusia.

Sesuai Pasal 45 huruf (b) dan huruf (c), preferensi bagi bank untuk agunan berupa tanah, gedung, rumah tinggal dan mesin akan diperoleh apabila agunan dimaksud diikat dengan hak tanggungan. Pengikatan agunan secara hak tanggungan harus sesuai dengan ketetuan dan prosedur dalam peraturan perundang-undangan yang berlaku yaitu Undang-Undang Nomor 4 Tahun 1996 tentang Hak Tanggungan, termasuk namun tidak terbatas pada masalah pendaftaran, sehingga bank memiliki hak preferensi terhadap agunan yang diikat dengan hak tanggungan.

\section{Kedudukan Hak Tanggungan dalam Pembiayaan di Perbankan Syariah}

Adanya jaminan dalam lembaga keuangan merupakan suatu usaha yang dilakukan dalam melaksanakan prinsip kehati-hatian dalam menjalankan fungsinya sebagai lembaga penyalur dana kepada masyarakat. ${ }^{10}$ Peran jaminan dalam memberikan pembiayaan atau kredit memberikan keyakinan kepada bank atas kesanggupan debitur dalam melunasi kredit yang telah dilakukan. Sedangkan objek jaminan yang diberikan kepada perbankan merupakan jaminan tambahan atau jaminan pelengkap (accesoir) yang lahir dari adanya suatu jaminan pokok yang berupa hutang piutang. ${ }^{11}$

Jaminan dapat dibedakan menjadi dua macam, yaitu jaminan kebendaan dan jaminan perorangan. Jaminan kebendaan memberikan hak mendahului di atas bendabenda tertentu dan mempunyai sifat melekat dan mengikuti benda yang bersangkutan. Sedangkan jaminan peorangan tidak memberikan hak mendahului atas benda-benda tertentu, tetapi hanya djamin oleh harta kekayaan seseorang lewat orang yang menjamin pemenuhan perikatan yang bersangkutan. Berlakunya perjanjian jaminan selalu bergantung dengan perjanjian pokoknya. Apabila perjanjian pokoknya selesai maka

9 Gatot Supramono, Perbankan dan Masalab Kredit (Suatu Tinjanan di Bidang Yuridis), PT Rineka Cipta, Jakarta, 2009, hlm. 181.

10 Zainuddin Ali, Hukum Perbankan Syariah, Sinar Grafika, Jakarta, 2007, hlm. 1.

11 A. Wangsawidjaja Z, Pembiayaan Bank Syariah, Gramedia Pustaka Utama, Jakarta, 2012, hlm. 285. 
perjanjian jaminannya juga ikut selesai, sebab tidak mungkin ada orang yang bersedia menjamin utang kalau utang tersebut tidak ada wujudnya.

Untuk dapat membuat perjanjian jaminan maka dalam perjanjian pokoknya dapat disebutkan secara sederhana tentang adanya janji-janji mengenai jaminan. Dengan janjijanji ini dipergunakan sebagai sumber untuk terbitnya perjanjian jaminan yang dikehendaki oleh kreditur dan debitur. Jadi ketika membuat perjanjian jaminan, hal ini merupakan salah satu pelaksanaan dari perjanjian pokok.

Aturan hukum perdata tentang jaminan terdapat dalam KUH Perdata Pasal 1131 yang berbunyi "segala barang-barang bergerak dan tidak bergerak milik debitur, baik yang sudah ada maupun yang akan ada, menjadi jaminan untuk perikatan-perikatan perorangan debitur itu." Dengan arti lain bahwa suatu kewajiban bagi debitur untuk memberikan jaminan kepada kreditur atas utang yang telah diterimanya, tanpa adanya jaminan yang ditentukan secara khusus maka segala harta kekayaan debitur baik yang telah ada maupun yang akan ada secara otomatis menjadi jaminan ketika orang tersebut membuat perjanjian utang meskipun hal tersebut tidak dinyatakan tegas dalam perjanjian.

Dari peraturannya di dalam KUHPerdata dapat disimpulkan terdapat dua macam jaminan, yaitu jaminan umum dan jaminan khusus. Jaminan umum lahir dari Undangundang, tanpa adanya perjanjian yang diadakan oleh para pihak lebih dulu, para kreditur secara bersama memperoleh jaminan umum yang diberikan oleh undangundang. Dalam jaminan umum ini, semua barang-barang milik debitur secara otomatis merupakan jaminan bagi para kreditur tanpa memandang siapa yang lebih dahulu membuat perjanjian pokoknya. Semua kreditur mempunyai hak yang sama terhadap objek jaminan, namun mengenai pembayaran utang tidak dibagi rata dari hasil penjualan barang tersebut. Sedangkan jaminan khusus yaitu hanya kreditur tertentu dan benda jaminanannya ditunjuk secara khusus pula yaitu berupa Gadai, Fidusia, Hak Tanggungan, dan Garansi Bank. Jaminan khusus lahir karena adanya perjanjian yang khusus dilakukan oleh kreditur dan debitur yang dapat berupa jaminan yang bersifat kebendaan maupun jaminan yang bersifat perorangan.

Seperti halnya jaminan dalam hukum perdata, jaminan dalam perbankan syariah dibagi menjadi ada dua macam yaitu Kafalah (jaminan perorangan) dan Rahn (jaminan kebendaan). Kafalah adalah akad pemberianjaminan (makful alaih) yang diberikan satu pihak kepada pihak lain dimana pemberi jaminan (kafil) bertanggung jawan atas pembayaran kembali suatu utang yang menjadi hak penerima jaminan (makful).12 Dalam perbankan konvensional atau yang sesuai dengan ketentuan KUH Perdata, kafalah tidak lain adalah perjanjian borgtocht atau guarantee, baik berupa personal guarantee maupun coorpoorate guarantee. Ketentuan kafalah tercantum dalam Fatwa Dewan Syariah Nasional Nomor 11/DSN-MUI/IV/2000 Tentang Kafalah.

Ar-rahn, merupakan akad penyerahan barang/harta (mahrun) dari nasabah (rahun) kepada bank (murtahin) sebaga jaminan sebagian atau seluruh utang. Dalam perbankan konvensional atau yang sesuai dengan ketentuan KUH Perdata, Ar-Rahn tidak lain adalah jaminan kebendaan. Fatwa Dewan Syariah Nasional Nomor 25/DSNMUI/III/2002 tentang Rahn menjelaskan bahawa pinjaman dengan menggadaikan

\footnotetext{
${ }^{12}$ Faturrahman Djamil, Op. Cit., hlm. 56
} 
barang sebagai jaminan utang dalam bentuk Rahn dibolehkan dengan beberapa ketentuan yang diatur dalam fatwa ini.

Lembaga jaminan kebendaan yang diatur dalam Undang-Undang Nomor 10 Tahun 1998 tentang Perbankan dalm Pasal 8 ayat (1) menyatakan bahwa bank dalam memberikan kredit atau pembiayaan berdasarkan prinsip syariah, bank umum wajib mempunyai keyakinan berdasarkan analisis yang mendalam atas iktikad dan kemampuan serta kesanggupan nasabah debitur untuk melunasi utangnya atau mengembalikan pembiayaan dimaksud sesuai dengan yang diperjanjikan. Pasal 8 ayat (2) menyatakan Bank Umum wajib memiliki dan menerapkan pedoman perkreditan dan pembiayaan berdasarkan prinsip syariah, sesuai dengan ketentuan yang ditetapkan oleh Bank Indonesia.

Hak tanggungan adalah jaminan kebendaan yang dikategorikan sebagai jaminan khusus dalam KUH Perdata. Hak Tanggungan merupakan jaminan yang banyak digunakan oleh bank untuk memberikan kredit dalam perbankan konvensional dan pembiayaan dalam perbankan syariah. Hak tanggungan merupakan perjanjian jaminan yang bersifat accessoir (tambahan), yaitu merupakan perjanjian jaminan yang selalu mengikuti perjanjian pokoknya dan lahir karena adanya perjanjian pokok, tetapi sebaliknya perjanjian pokok tidak selalu menimbulkan perjanjian jaminan. Hak tanggungan dibebankan pada hak atas tanah beserta atau tidak beserta benda-benda lain yang merupakan satu kesatuan dengan tanah itu. Adapun yang menjadi obyek hak atas tanah yang dapat dibebankan hak tanggungan adalah Hak Milik, Hak Guna Usaha, Hak Guna Bangunan, Hak Pakai atas tanah negara.

Kedudukan Hak Tanggungan sebagai jaminan dalam bank konvensional merupakan suatu keharusan dikarenakan bank konvensional dalam menyalurkan fasilitas kredit selalu mengedepankan aspek jaminan untuk mengamankan kreditnya. Hak tanggungan adalah hak jaminan atas tanah untuk pelunasan utang tertentu, yang memberikan kedudukan diutamakan kepada kreditor-kreditor lainnya. Dalam arti, bahwa jika debitor cidera janji, kreditor pemegang Hak Tanggungan berhak menjual melalui pelelangan umum tanah yang dijadikan jaminan menurut ketentuan peraturan perundang-undangan yang bersangkutan atau juga dapat dilakukan dengan cara "parate executie" sebagaimana diatur dalam Pasal 224 HIR dan Pasal RBg bahkan dapat pula dilakukan dengan penjualan dibawah tangan, dengan hak mendahului daripada kreditor-kreditor yang lain. Dalam Pasal 7 UUHT, hak tanggungan selalu mengikuti objek yang dijaminkan dalam tangan siapapun objek benda itu berada. Sifat ini merupakan salah satu jaminan khusus bagi pemegang hak tanggungan. Meskipun objek hak tanggungan telah berpindah tangan dan menjadi milik pihak lain, namun kreditor masih tetap dapat menggunakan haknya untuk melakukan eksekusi apabila debitor cidera janji. Selain itu, eksekusi hak tanggungan mudah dan pasti sehingga debitor tidak perlu menempuh acara gugatan perdata yang memerlukan waktu dan biaya yang tidak sedikit.

Hak Tanggungan sebagai jaminan namun kedudukan hak tanggungan berbeda antara bank konvensional dan bank syariah. Posisi jaminan dalam Bank Syariah bukanlah hal yang pokok dalam pemberian dana pembiayaan. Rahn, istilah jaminan kebendaan dalam bank syariah merupakan hal yang dibolehkan sesuai dengan prinsip syariah namun Rahn tidak diwajibkan adanya ketika terjadi suatu perjanjian pembiayaan 
dalam perbankan syariah karena pada dasarnya jaminan dalam bank syariah bukan sebagai pengganti utang melainkan penjamin utang nasabah.

Pembiayaan Musyarakah yang berdasarkan Fatwa Dewan Syariah Nasional Nomor 08/DSN-MUI/IV/2000, adanya jaminan dalam Pembiayaan Musyarakah hanya untuk memberikan kepastian kepada pihak bank bahwa nasabah akan menggunakan dana dari bank tersebut sesuai dengan kesepakatan di awal perjanjian pembiayaan tersebut dibuat. ${ }^{13}$ Dikarenakan bank syariah dalam meberikan pembiayaan berdasar pada prinsip investasi, dimana setiap investasi mempunyai kemungkinan untung dan rugi. Sehingga bank syariah lebih mengutamakan kelayakan usaha setiap calon mitra/nasabah pembiayaan dan aspek kemitraan. Pada dasarnya, dalam pembiayaan musyarakah tidak ada jaminan, namun untuk menghindari terjadinya penyimpangan yang dilakukan nasabah maka bank syariah meminta jaminan. Dalam arti lain, jaminan bukanlah hal yang pokok dalam pembiayaan musyarakah, melainkan kedudukan jaminan hanya sebagai sebagai prinsip kehati-hatian bank syariah dalam memberikan pembiayaan kepada nasabah.

Dalam Fatwa Dewan Syariah Nasional Nomor 04/DSN-MUI/IV/2000 Tentang Murabahah menyatakan bahwa jaminan dalam Murabahah dibolehkan, agar nasabah serius dengan pesanannya dan bank dapat meminta nasabah untuk menyediakan jaminan yang dapat dipegang. Dari pernyataan tersebut, pada dasarnya jaminan dalam pembiyaan Murabahah merupakan hal yang dibolehkan dan bukanlah sesuatu yang pokok yang harus ada dalam pembiayaan Murabahah. Jaminan dalam pembiayaan Murabahah hanya untuk memberikan kepastian kepada pihak $b a^{\prime} i$ (penjual) bahwa pihak musytari (pembeli) dalam pembiayaan Murabahah akan serius dengan pesanannya sesuai dengan yang telah diperjajikan di awal. Kedudukan jaminan dalam pembiayaan Murabahah bukanlah untuk menjamin atas modal yang dikeluarkan oleh bank dan jaminan bukanlah hal yang harusada dalam pembiayaan Murabahah, dalam arti lain bahwa tanpa adanya jaminan pembiayaan Murabahah sudah dapat disetujui dan berlaku.

\section{Penutup}

\section{Kesimpulan}

Legalitas Hak Tanggungan dalam pembiayaan di perbankan syariah dapat dilihat dari adanya lembaga Hak Tanggungan yang berdasarkan UUHT terkait legalitas pembebanan hak tanggungan pada perbankan syariah didasarkan pula pada bentuk Akta Pembebanan Hak Tanggungan (APHT) dan/atau Surat Kuasa Membebankan Hak Tanggungan (SKMHT) yang dibuat oleh Pejabat Pembuat Akta Tanah (PPAT), yang selanjutnya dikaitkan dengan makna akad-akad dalam pembiayaan di bank syariah. Selain itu, legalitas hak tanggugan dalam pembiayaan di perbankan syariah diperkuat dengan adanya Peraturan Otoritas Jasa Keuangan Nomor 16/POJK.03/2014 tentang Penilaian Kualitas Aset Bank Umum Syariah dan Unit Usaha Syariah.

Kedudukan Hak Tanggungan dalam Bank Konvensional dan Perbankan Syariah berbeda. Hak Tanggungan sebagai jaminan dalam Bank Konvensional merupakan suatu

13 Dewi Nurul Musjtari, Penyelesaian Sengketa Akad Pembiayaan dengan Jaminan Hak Tanggungan Dalam Praktik Perbankan Syariah, Parama Publishing, Yogyakarta, 2016, hlm. 136. 
keharusan dikarenakan bank konvensional dalam menyalurkan fasilitas kredit selalu mengedepankan aspek jaminan untuk mengamankan kreditnya. Hak Tanggungan memberikan kedudukan diutamakan kepada kreditor-kreditor lainnya, yang artinya bahwa jika debitor cidera janji, kreditor pemegang Hak Tanggungan berhak menjual melalui pelelangan umum tanah yang dijadikan jaminan menurut ketentuan peraturan perundang-undangan yang bersangkutan atau juga dapat dilakukan dengan cara "parate executie" sebagaimana diatur dalam Pasal 224 HIR dan Pasal 158 RBg bahkan dapat pula dilakukan dengan penjualan di bawah tangan, dengan hak mendahului daripada kreditor-kreditor yang lain. Selain itu, hak tanggungan selalu mengikuti objek yang dijaminkan dalam tangan siapapun objek benda itu berada serta mudah dan pasti dalam eksekusinya. Sedangkan dalam perbankan syariah, Hak Tanggungan tidak berkedudukan prevelige dalam pemberian dana pembiyaan.

\section{Saran}

Dalam pembebanan Hak Tanggungan dalam Perbankan Syariah, Kantor Pertanahan haruslah terlebih dahulu memperhatikan maksud dari pembiayaan dalam Perbankan Syariah sehingga tidak ada pengubahan redaksi-redaksi baku yang sudah ditetapkan oleh Perkaban terkait dengan APHT. Untuk Pemerintah, seharusnya UndangUndang Nomor 21 Tahun 2008 Tentang Perbankan Syariah lebih spesifik mengatur jaminan apa saja yang dapat digunakan dalam pembiayaan di perbankan syariah. Dewan Syariah Nasional sebagai lembaga yang berwenang dalam hal Perbankan Syariah agar lebih jelas membuat peraturan khusus yang akan digunakan sebagai landasan pembebanan Hak Tanggungan sebagai lembaga jaminan kebendaan yang digunakan dalam pembiayaan di Perbankan Syariah.

\section{Daftar Pustaka}

\section{Buku}

Djamil, Faturrahman, Penyelesaian Pebiayaan Bermasalah di Bank Syarah, Sinar Garfika, Jakarta, 2012.

Mahmud Marzaki, Peter, Penelitian Hukum, Edisi Pertama Cetakan ke-4 Prenada Media Group, Jakarta, 2015. Penelitian Hukum, Prenada Media Group, Jakarta, 2011.

Muljadi, Kartini dan Gunawan Widjaja, Hak Tanggungan, Kencana Prenada Media Group, Jakarta, 2005.

Nawawi, Ismail, Perbankan Syariah di Indonesia, Kencana, Jakarta, 2011.

Nurul Musjtari, Dewi, Penyelesaian Sengketa Akad Pembiayaan dengan Jaminan Hak Tanggungan dalam Praktik Perbankan Syariah, Parama Publishing, Yogyakarta, 2016.

Supramono, Gatot, Perbankan dan Masalah Kredit (Suatu Tinjauan di Bidang Yuridis), PT Rineka Cipta, Jakarta, 2009.

Triyanta, Agus, Hukum Perbankan Syariah, Setara Press, Malang, 2016

Z, Wangsawidjaja, Pembiayaan Bank Syariah, Gramedia Pustaka Utama, Jakarta, 2012. 
392 Officium Notarium NO. 1 VOL. 1 APRIL 2021: 380-392

\section{Peraturan Perundang-undangan}

Kitab Undang-Undang Hukum Perdata

Undang-Undang Nomor 4 Tahun 1996 tentang Hak Tanggungan Atas Tanah Beserta Benda-benda yang Berkaitan Dengan Tanah

Undang-Undang Nomor 21 Tahun 2008 tentang Perbankan Syariah 